\title{
Presence, abundance and bacterivory of the mixotrophic algae Pseudopedinella (Dictyochophyceae) in freshwater environments
}

\author{
Marina Gerea $^{1, *}$, Juan F. Saad ${ }^{2}$, Irina Izaguirre ${ }^{2}$, Claudia Queimaliños ${ }^{1}$, \\ Josep M. Gasol ${ }^{3}$, Fernando Unrein ${ }^{4}$ \\ ${ }^{1}$ Laboratorio de Fotobiología, INIBIOMA, CONICET-Universidad Nacional del Comahue, Quintral 1250, \\ (R8400FRD) Bariloche, Argentina \\ ${ }^{2}$ Departamento de Ecología, Genética y Evolución, IEGEBA, UBA-CONICET, Ciudad Universitaria, \\ (C1428EHA) Buenos Aires, Argentina \\ ${ }^{3}$ Institut de Ciències del Mar, CSIC, Passeig Marítim de la Barceloneta, 37-49. 08003 Barcelona, Catalonia, Spain \\ ${ }^{4}$ Laboratorio de Ecología y Fotobiología Acuática, IIB-INTECH, UNSAM-CONICET, Av. Intendente Marino km 8, 200, \\ (B7130IWA) Chascomús, Argentina
}

\begin{abstract}
The genus Pseudopedinella has been described as mixotrophic; however, ecological information about this algal stramenopile (Heterokonta) is unclear. We investigate the environmental conditions that determine the presence, abundance and bacterivory rates of this genus in freshwater systems. To this end we analyzed 54 water bodies with different limnological features distributed along a latitudinal and trophic gradient in northern Patagonia (Argentina) and the Antarctic Peninsula. In addition, 14 grazing experiments were carried out in order to estimate ingestion rates and impact on the bacterioplankton. Our results indicate that this genus is exclusively found in oligotrophic environments, and that it develops well in a wide range of temperatures. Average cell-specific grazing rate was 2.83 bacteria cell $^{-1} \mathrm{~h}^{-1}$, with a maximum value of 6.74 bacteria $\mathrm{ml}^{-1} \mathrm{~h}^{-1}$. Interestingly, grazing increased with prey abundance and decreased with increasing nutrient availability. These patterns are common in highly bacterivorous protists that use phagotrophy as a main source of nutrient acquisition. Despite their usually low abundance (avg. 182 cells ml $^{-1}$ ), this single genus was responsible for up to $24 \%$ (avg. $10 \%$ ) of the total grazing impact exerted by all phagotrophs in these lakes. Overall, our results support the idea that Pseudopedinella is a highly bacterivorous group of freshwater protists, with the ability to develop well in oligotrophic conditions and with a potentially significant impact on bacterioplankton.
\end{abstract}

KEY WORDS: Pseudopedinella $\cdot$ Bacterivory $\cdot$ Grazing rate $\cdot$ Patagonian lakes $\cdot$ Antarctic lakes

\section{INTRODUCTION}

Among planktonic algae the phenomenon of mixotrophic nutrition, that is the combination of phagotrophy and phototrophy, has been known for about a century (Biecheler 1936). Nevertheless, the relevance of these algae as bacterivores in pelagic trophic webs was only recognized a few decades ago (Bird \& Kalff 1986, Nygaard \& Tobiesen 1993). Nowadays, mixotrophy is considered a key life strategy among marine and freshwater organisms (Gasol et

*Corresponding author: geream@comahue-conicet.gob.ar al. 2008, Flynn et al. 2013). Mixotrophic flagellates (MF) are major grazers of bacteria in oligotrophic systems, often being responsible for $>50 \%$ of the total bacterivory (Bird \& Kalff 1986, Unrein et al. 2007, Hartmann et al. 2012).

Mixotrophy is widespread among phytoplankton (Tranvik et al. 1989, Nygaard \& Tobiesen 1993, Stoecker et al. 1997) and it has been demonstrated in many algal groups, such as chrysophytes, haptophytes, dinoflagellates, cryptophytes, prasinophytes and raphidophytes (Bird \& Kalff 1986, Stoecker 1999,

(C) The authors 2016. Open Access under Creative Commons by Attribution Licence. Use, distribution and reproduction are unrestricted. Authors and original publication must be credited. 
Callieri et al. 2006, Unrein et al. 2007, 2014, Carvalho \& Granéli 2010, Jeong et al. 2010, Maruyama \& Kim 2013, McKie-Krisberg et al. 2015). Several studies have attempted to classify mixotrophs into categories based on the relative importance of their phagotrophic and phototrophic activities (Jones 1994, 2000, Stoecker 1998). While some discrepancies exist, most studies agree that each taxon differs regarding the relative magnitude of both modes of nutrition, and consequently in their potential impact on Bacteria and Archaea (from now on bacterioplankton for simplicity). However, there are relatively few investigations carried out on natural communities that comparatively analyze in situ bacterivory rates and grazing impact among various MF. The available data suggest that the chrysophytes are one of the most 'heterotrophic' algae, with high relative contribution of phagotrophy to their growth (Sanders et al. 1990, Olrik 1998, Rottberger et al. 2013) and high impact on the bacterial community in oligotrophic lakes (Bird \& Kalff 1986, Schmidtke et al. 2006, Unrein et al. 2010). Nevertheless, some differences could be expected among genera or species belonging to the same class. In this sense, comparative analyses evaluating the physiological range of two strains of mixotrophic chrysophytes (Dinobryon divergens and Poterioochromonas malhamensis) have demonstrated marked differences in the contribution of phagotrophy to their nutritional requirements (Rottberger et al. 2013).

Heterotrophic nutrition in the stramenopile (Heterokonta) Pseudopedinella has been long recognized (Porter 1988, Havskum \& Riemann 1996, Sekiguchi et al. 2003, Stauffer et al. 2008). However, to the best of our knowledge, its impact on the bacterioplankton has been quantified only twice (Nygaard \& Tobiesen 1993, Havskum \& Riemann 1996). The taxonomic status of this genus has changed during the last few decades. Within the group Stramenopiles, Pseudopedinella was first considered a member of the class Chrysophyceae, while since the 1980s it has been included within the class Dictyochophyceae (Hibberd 1986, Kristiansen \& Sandgren 1986, Kristiansen 1990). However, several ecological studies still include this nanoplanktonic genus in the Chrysophyceae (see references in Table S1 in the Supplement at www.intres.com/articles/suppl/a076p219_supp.pdf). Its usually low abundance in natural samples and the misplacement within the class Chrysophyceae in many studies might explain the lack of information about this genus with respect to its environmental requirements, distribution and impact on bacterioplankton.

As a general trend, the phytoplankton community of Antarctic and most Patagonian lakes is dominated by nanoplanktonic flagellated algae (Izaguirre et al. 1998, 2003, Queimaliños \& Diaz 2014). In particular, Pseudopedinella sp. were detected in some oligotrophic Antarctic lakes using molecular fingerprinting and microscopic techniques (Unrein et al. 2005). In the present investigation, we studied 54 water bodies located along a latitudinal gradient from North Patagonia to the Antarctic Peninsula covering a wide variety of lake types. The aim of this study was to analyze in detail the cellular morphology of this genus, and identify the main environmental variables that constrain the presence, abundance, grazing rates and impact of Pseudopedinella on the bacterioplankton. We hypothesized that Pseudopedinella might exhibit high in situ bacterivory rates comparable with other heterotrophic organisms, and might significantly impact on bacterioplankton communities. As mentioned above, different MF might differ in the use of phagotrophy for growth and consequently in their impact on bacterioplankton. Increasing our knowledge about the ecological requirements and grazing rates of each MF taxa will help to better understand their role on microbial trophic webs. In the present manuscript, we contribute to the characterization of Pseudopedinella sp. as a potentially significant bacterivore.

\section{MATERIALS AND METHODS}

\section{Study site}

A total of 54 lakes were sampled along a northsouth transect of $2800 \mathrm{~km}$, from $41^{\circ} 03^{\prime} \mathrm{S}$ in North Patagonia (Argentina) to $63^{\circ} 23^{\prime} \mathrm{S}$ in the Antarctic Peninsula (Fig. 1). Patagonian lakes are categorized as belonging to 2 different geographical regions according to their geological origin: 'Patagonian Plateau Region' and 'Andean Patagonian Region' (Iriondo 1989, Quirós \& Drago 1999). Lakes located in the first area are generally shallow and mesotrophic to eutrophic, whereas Andean Patagonian lakes are of glacial origin and consequently deeper than the Plateau lakes. Due to the rocky basin formation of the Andean lakes, they often present oligotrophic and ultraoligotrophic status. Mean annual temperature in Patagonia ranges from $12^{\circ} \mathrm{C}$ in the northeast to $3^{\circ} \mathrm{C}$ towards the south. From the Andes and eastward, total annual precipitation decreases exponentially from ca. 2000 to $<200 \mathrm{~mm} \mathrm{yr}^{-1}$ in the central portion of Patagonia (Paruelo et al. 1998). The studied Antarctic lakes are located in Hope Bay at the Northern end of the Antarctic Peninsula. Most of them are shallow and of glacial origin. Extensive information 


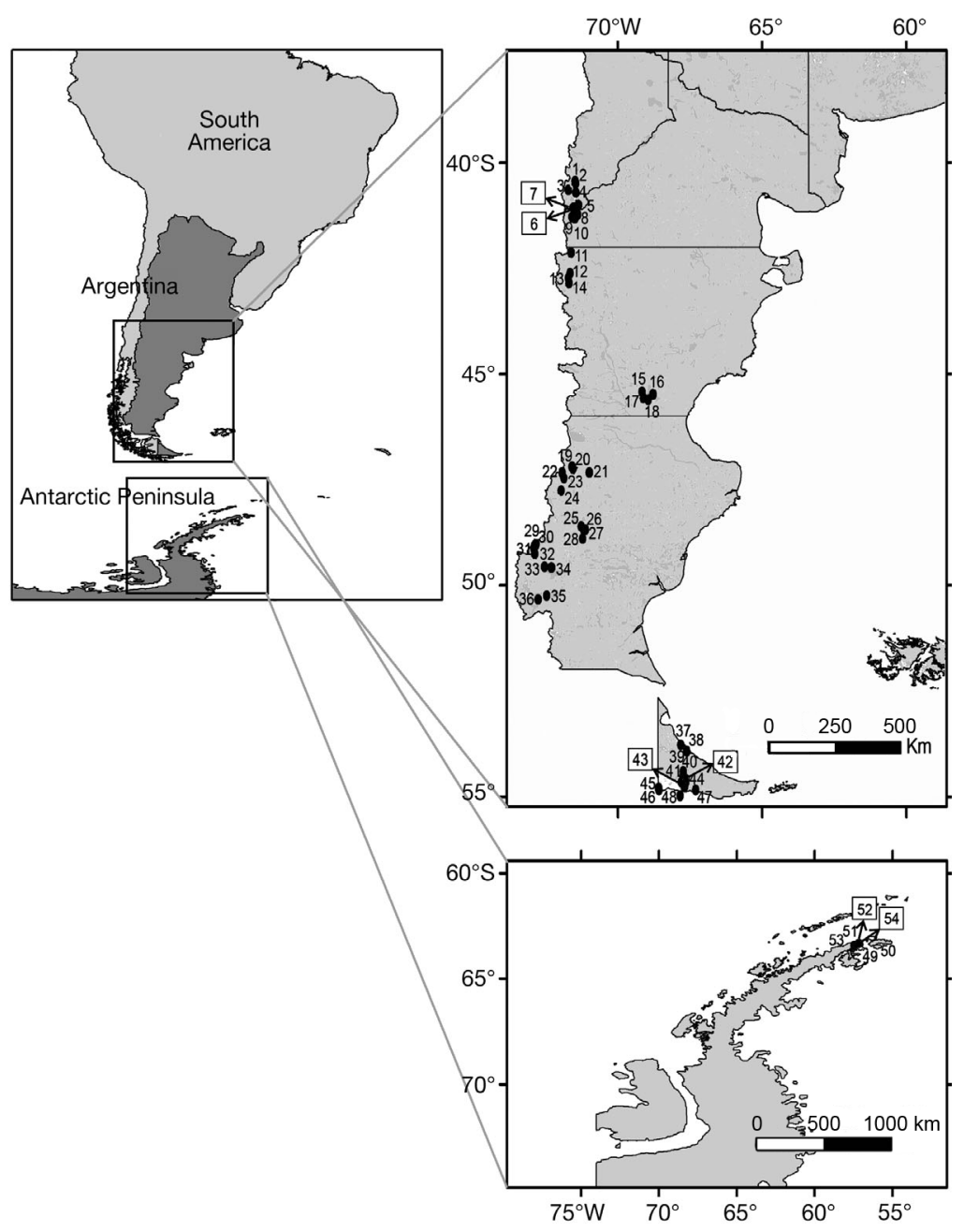

Fig. 1. Location of 54 water bodies along a north-south transect in Patagonia (Argentina) and the Antarctic Peninsula that were studied to determine the presence, abundance and bacterivory rates of Pseudopedinella spp. See Table S2 in the Supplement for detailed information on each lake. The 6 lakes selected for grazing experiments (Nos. 6, 7, 42, 43, 52 and 54) are indicated with a square and arrows

about all sampled lakes, including the main abiotic variables, is available in several studies (Izaguirre et al. 1998, 2003, Unrein et al. 2005, Callieri et al. 2007, Schiaffino et al. 2011, Gerea 2013, Saad et al. 2013).

Data were collected during five different campaigns: (1) 12 lakes from North Patagonia were sampled once between December 2001 and February 2002; (2) 2 shallow lakes from North Patagonia were sampled monthly between November 2009 and January 2011 (except in July and December 2010), at 4 different depths $(0,3,6$ and $8 \mathrm{~m})$ on each date; (3) 22 water bodies from South Patagonia (continental) were sampled once in November 2007; (4) 11 water bodies from South Patagonia (Tierra del Fuego Island) were sampled once in November 2008, and 3 of these lakes and 1 additional lake were sampled again in January 2010. Finally, (5) the 6 Antarctic water bodies were sampled twice between January and February 2004. Detailed information about each water body is presented in Table S2 in the Supplement at www.int-res.com/ articles/suppl/a076p219_supp.pdf.

\section{Sampling data}

In the different campaigns three general types of water bodies were sampled: deep lakes (DL), shallow lakes (SL) and temporary ponds (P). For deep lakes, integrated samples were collected within the epilimnetic layers from the surface down to $5 \mathrm{~m}$, whereas samples of shallow lakes and temporary ponds were obtained from about $30 \mathrm{~cm}$ below the surface. For each water body we determined in situ conductivity, $\mathrm{pH}$, dissolved oxygen (DO) and water temperature using standard instruments (Saad et al. 2013). Samples collected in each water body were transferred to acid-washed and pre-rinsed plastic bottles, and were transported to the laboratory in darkness. The concentration of nutrients, i.e. ammonium-N $\left(\mathrm{NH}_{4}\right)$, nitrate- $\mathrm{N}\left(\mathrm{NO}_{3}\right)$, nitrite- $\mathrm{N}\left(\mathrm{NO}_{2}{ }^{-}\right)$ and soluble reactive phosphorus (SRP), phytoplanktonic chlorophyll a (chl a) and dissolved organic carbon (DOC) were analyzed following the methods already described in Saad et al. (2013). Dissolved inorganic nitrogen (DIN) was defined as the sum of nitrate, nitrite and ammonium.

Samples for Pseudopedinella identification and quantification were fixed with ice-cold filtered glutaraldehyde $10 \%$ (final concentration 1\%). Between 15 and $40 \mathrm{ml}$ of the fixed sampled were filtered through a $0.8 \mu \mathrm{m}$ polycarbonate black filter (Millipore) stained with $5 \mathrm{\mu g} \mathrm{ml}^{-1}$ (final concentration) of 4', 6-diamidino-2-phenylindole (DAPI) according to Porter \& Feig (1980). The filters were mounted over microscope slides using immersion oil for fluorescence microscopy and were stored at $-20^{\circ} \mathrm{C}$. The samples were inspected under $1000 \times$ magnification using an epifluorescence microscope (Olympus BX50), equipped with an HBO 50 lamp and a filter set for blue light, green light and UV excitation. Abundances of Pseudopedinella as well as of other autotrophic, MF and heterotrophic (HF) nanoplanktonic 
organisms were determined. For further explanation of the classification of autotrophic and mixotrophic phytoplankton taxa see the description of 'Grazing experiments' below. We used these results to compare the relative abundance of Pseudopedinella in relation to different variables.

Three different analyses and a series of grazing experiments were performed on different samples as described below; further are provided in Table S2 in the Supplement.

\section{Analyses of samples}

\section{Morphology of Pseudopedinella}

To analyze the morphology and size of Pseudopedinella cells, we randomly selected 14 out of the 30 water bodies where this algae was present. About 40 pictures were obtained from the DAPI-stained sample. The images were analyzed with the software Image Pro Plus 4.5. Between 20 and 49 individuals were measured per lake (avg. 30). The cellular volume $\left(\mu \mathrm{m}^{3}\right)$ was estimated for each individual by applying the geometric models proposed by Sun \& Liu (2003). An average value of the cellular volume was obtained for each lake. The algal biomass was estimated using the formula presented by MendenDeuer \& Lessard (2000), where algal biomass (pg C cell $\left.^{-1}\right)=0.216 \times\left(\text { algal volume }\left[\mu^{3} \operatorname{cell}^{-1}\right]\right)^{0.939}$.

\section{Presence and abundance of Pseudopedinella}

To determine the variables that constrain the presence and abundance of Pseudopedinella, we used all the data, in order to cover as many different limnological conditions as possible. For this purpose, we considered the 54 sampled water bodies. For the analysis, we considered 43 aquatic systems which were sampled once, and 11 which were sampled twice. Thus, the analysis included a total of $65(43+22)$ samples. Among the water bodies sampled twice, we included the 2 spring data sets (November 2009 and November 2010) of the 2 shallow North Patagonian lakes which were sampled during an annual period (Campaign 2; Table S2 in the Supplement).

Vertical and temporal variation of Pseudopedinella

With the aim of analyzing variations in the abundance of Pseudopedinella with time and depth the complete dataset of the longest campaign (Campaign 2) was considered. The 2 sampled water bodies, Morenito and Escondido North, are neighboring oligotrophic shallow lakes from North Patagonia. Both share roughly similar abiotic features but present different DOC concentrations and underwater light conditions (M. Gerea et al. unpubl. data).

\section{Grazing experiments}

Six lakes in which Pseudopedinella was present were selected to analyze its grazing activity and impact on the bacterial community: SL Morenito, SL Escondido North (Nahuel Huapi National Park), DL Escondido South (Tierra del Fuego National Park), SL Victoria, SL Esperanza, and SL Encantado. A total of 14 grazing experiments were performed using fluorescently labeled bacteria (FLB) as a tracer. FLB were prepared from a culture of Brevundimonas diminuta (syn. Pseudomonas diminuta) following the technique described in Unrein et al. (2007). B. diminuta has previously been used to prepare FLB because of their relatively small size (average size: $0.33 \mu \mathrm{m}$ wide, $0.76 \mu \mathrm{m}$ length, $0.065 \mu^{3}$ volume) (Unrein et al. 2007, Izaguirre et al. 2012), which is comparable to that of the indigenous bacteria in the studied lakes (0.26 to $0.33 \mu \mathrm{m}$ wide and 0.48 to $0.56 \mu \mathrm{m}$ length, 0.031 to $0.056 \mu \mathrm{m}^{3}$ volume). For each experiment we collected $5 \mathrm{l}$ of lake water in an acid washed plastic bottle thoroughly rinsed with distilled water. Water samples were gently filtered through a zooplankton mesh to reduce the presence of large predators (e.g. copepods, cladocerans) in the sample. Experiments were run in triplicate. In those performed in Antarctica and in South Patagonia, bottles were incubated in situ $30 \mathrm{~cm}$ beneath the water surface. Due to the logistical impossibility of incubating the bottles in situ, the experiments performed in North Patagonia were placed in an incubation chamber at a fixed light intensity of $100 \mu \mathrm{mol}$ photons $\mathrm{m}^{-2} \mathrm{~s}^{-1}$ and at the in situ photoperiod and temperature conditions. The mean irradiance in the water column over the year averaged $151 \mu \mathrm{mol}$ photons $\mathrm{m}^{-2} \mathrm{~s}^{-1}$ (range: 35 to $253 \mu \mathrm{mol}$ photons $\mathrm{m}^{-2} \mathrm{~s}^{-1}$ ) in SL Escondido North and $192 \mu \mathrm{mol}$ photons $\mathrm{m}^{-2} \mathrm{~s}^{-1}$ (range: 47 to $394 \mu \mathrm{mol}$ photons $\mathrm{m}^{-2}$ $\mathrm{s}^{-1}$ ) in SL Morenito (Gerea 2013). The concentration of tracer (FLB) used corresponded to about $20 \%$ of the natural abundance of the heterotrophic bacteria. Experimental samples were taken at three different times. The first extraction (T0) was immediately after the addition of the tracer, while the frequency of the following extractions (T1 and T2) varied in each set 
of experiments depending on the environment condition (mainly water temperature). Preliminary experiments in each environment revealed that ingestion rates were linear for the first $2 \mathrm{~h}$ in Antarctic lakes and for the first $45 \mathrm{~min}$ in Patagonian waters. Therefore, the frequency of subsampling in Antarctica was $1 \mathrm{~h}$, while in Patagonian experiments it was between 15 and $20 \mathrm{~min}$. From each replicate bottle, $100 \mathrm{ml}$ were fixed with the same volume of pre-filtered coldglutaraldehyde at $4 \%$ of concentration, to avoid the egestion of the ingested prey (Sanders et al. 1989).

Depending on the experiment, between 30 and $80 \mathrm{ml}$ of each fixed experimental samples T0, T1 and T2 were filtered through a $0.8-\mu \mathrm{m}$ pore size polycarbonate black filter (Millipore). In addition, a smaller volume (about $20 \mathrm{ml}$ ) of T0 fixed samples was filtered over $0.2 \mu \mathrm{m}$ filters. All samples were stained with DAPI following the technique described above. Filters mounted on slides were stored at $-20^{\circ} \mathrm{C}$ until processing. Samples were inspected at $1000 \times$ magnification under an epifluorescence microscope. Filters of $0.2 \mu \mathrm{m}$ pore size were used to estimate bacteria and FLB initial abundance. Protist abundances (autotrophic algae, MF and HF) and ingested FLB (presence of FLB inside digestive vacuoles of MF and HF) were quantified on the $0.8-\mu \mathrm{m}$ pore size filters. HFs were identified by their morphology, by the presence of a nucleus under UV excitation, and by the absence of red fluorescence (chlorophyll) under blue light excitation. Autotrophic algae, Pseudopedinella spp. and other MF were identified by their morphology and by the red color of chlorophyll autofluorescence under blue light excitation. Tracer particles (FLBs, appearing green) within each individual were also quantified at the same time. Between 50 and 80 cells of each group of bacterivores (i.e. Pseudopedinella, other MF and HF) were inspected in each sample to determine the ingestion rate. We classified the phytoplankton taxa either as autotrophic or mixotrophic depending on their phagotrophic capability, according to published data based on grazing experiments (Tranvik et al. 1989, Jones 1994, Queimaliños 2002) and to the results of our experiments with FLBs. Within 'other MF', we identified different genera of chrysophytes (e.g. Dinobryon and Ochromonas), cryptophytes, dinoflagellates and haptophytes; however, for the purpose of the present work they were all clustered into a single group. The identification of these taxa by epifluorescence is not always straightforward, in particular for smaller organisms. Therefore, in those cases where the identification of MF was not clear, and the specimen did not contain FLBs, the flagellate was considered to be an auto- troph. This decision probably led to an underestimation of the abundance of 'other $\mathrm{MF}^{\prime}$; nevertheless, the calculation of impact of total mixotrophs is not affected by this bias.

For each group of bacterivores, ingestion rates $\left(\right.$ FLB cell ${ }^{-1} \mathrm{~h}^{-1}$ ) were calculated over the regression slope of the average number of prey ingested per individual and time. Ingestion rate was considered significant when the $95 \%$ confidence intervals of initial and final time did not overlap (Rice 1988 cited in Havskum \& Riemann 1996). Clearance rates $\left(\mathrm{CR}_{;} \mathrm{nl} \mathrm{cell} \mathrm{C}^{-1} \mathrm{~h}^{-1}\right)$ were calculated by dividing the ingestion rate by the FLB concentration. Cellspecific grazing rates $\left(\mathrm{CSGR}_{i}\right.$ bacteria cell $\left.{ }^{-1} \mathrm{~h}^{-1}\right)$ were estimated by multiplying $\mathrm{CR}$ by the bacterial concentration, assuming that native bacteria and FLB were grazed upon at the same rates. The grazing impact $\left(\mathrm{GI}_{\text {; }}\right.$ bacteria $\mathrm{ml}^{-1} \mathrm{~d}^{-1}$ ) by each group of bacterivores was estimated by multiplying their CSGR by their abundance (cells $\mathrm{ml}^{-1}$ ). Total GI was estimated as the sum of the GI by all bacterivores in the sample. Bacterial turnover rates $(\%$ $\mathrm{d}^{-1}$ ) were estimated by expressing the GI (bacteria $\mathrm{ml}^{-1} \mathrm{~d}^{-1}$ ) as a percentage of the corresponding bacterial abundance (bacteria $\mathrm{ml}^{-1}$ ). The cell-specific ingestion rate, as percentage of the cell carbon per day $\left(\% \mathrm{~d}^{-1}\right)$, was calculated for Pseudopedinella by dividing its CSGRs expressed in biomass of bacteria (mg $\mathrm{C}$ bacteria cell ${ }^{-1} \mathrm{~d}^{-1}$ ) by the mean flagellate biomass (mg $\mathrm{C}$ cell $^{-1}$ ). We assumed a bacterial carbon content of $0.02 \mathrm{pg} \mathrm{C}^{\mathrm{C}} \mathrm{cell}^{-1}$ (Lee \& Fuhrman 1987).

\section{Statistical analyses}

The Kruskal-Wallis (K-W) test was used to analyze variations of Pseudopedinella cellular volume among lakes. The relationship between Pseudopedinella abundance and biological and physical environmental variables was assessed by means of Pearson correlations; Pseudopedinella abundance was compared among deep lakes, shallow lakes and temporary ponds using K-W analysis. Regression analyses were employed to assess the relationship between the total and relative abundance of Pseudopedinella and the various physico-chemical variables. Oneway ANOVA was applied to compare variations in the vertical distribution of Pseudopedinella in each of the two lakes sampled during an annual period. Regression analyses were applied to describe the relation between CSGR and biotic and abiotic variables. A multiple regression model was generated to 

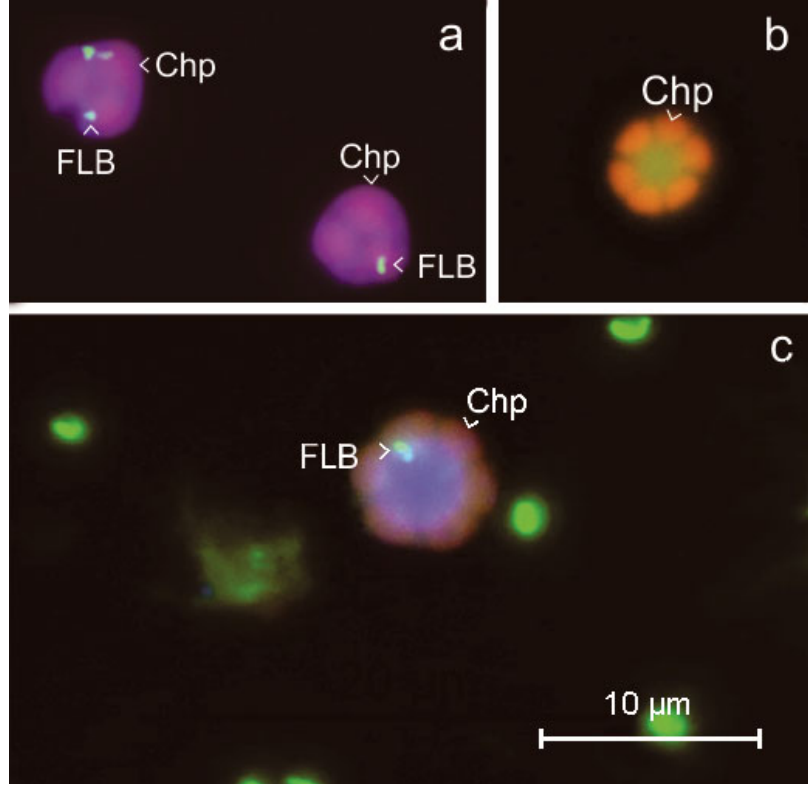

Fig. 2. Pseudopedinella spp. with (a) 3 chloroplasts (Chp) and $(\mathrm{b}, \mathrm{c})$ with 6 chloroplasts. Panels $(\mathrm{a})$ and $(\mathrm{c})$ show individuals with one or more fluorescently labeled bacteria (FLB) inside digestive vacuoles. Each of the images in panels (a) and (c) is an overlay of 2 pictures, one taken under UV excitation (to see the DNA stained with DAPI) and the other under blue light (to see the chlorophyll in red, and the FLB stained with DTAF in green); the image in panel (b) was taken under blue light excitation identify the most relevant variables explaining CSGR. Variables were log-transformed when the normality assumption was not met.

\section{RESULTS}

\section{Morphology}

Cells were always found solitary and free-living, and were observed from the anterior view. Pseudopedinella was unambiguously determined based on the characteristic radial symmetry and the absence of anterior tentacles, even though the stalk was never observed (Fig. 2). Cells with 3 (Fig. 2a) and 6 (Fig. 2b,c) peripheral chloroplasts could also be observed, probably indicating that more than 1 species was present in the studied lakes. Considering that the present work was focused on the genus, we did not discriminate among different species of Pseudopedinella, and hereinafter this group will be referred to as Pseudopedinella spp. In our samples, cell diameter ranged from 3.4 to $7.0 \mu \mathrm{m}$, and cellular volume from 31 to $183 \mu^{3}$. The K-W analysis indicated significant variations of the cellular volume of Pseudopedinella spp. among the studied lakes $(\mathrm{p}<0.001$; Fig. 3).

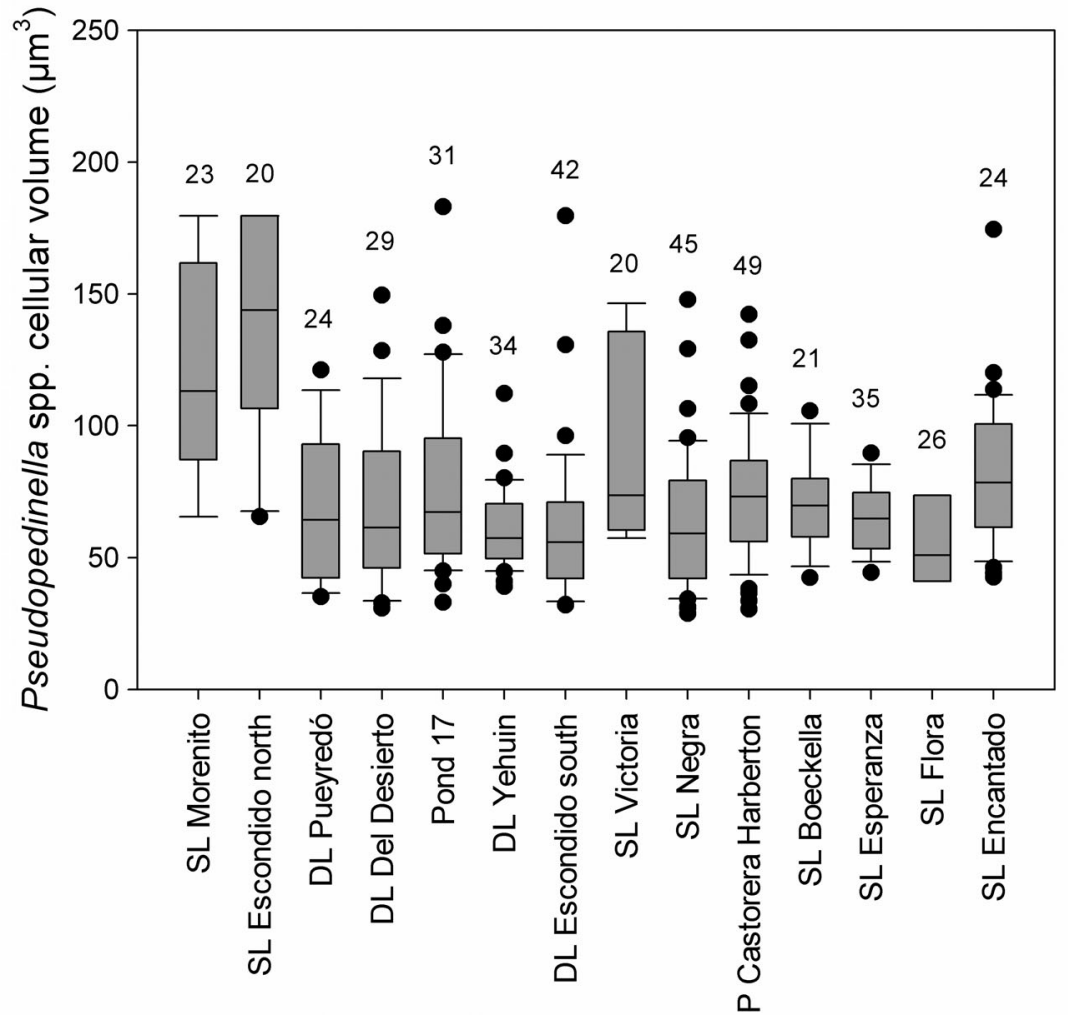

\section{Presence and distribution}

Pseudopedinella spp. were found in 30 out of 54 lakes regardless of latitude. Their abundances ranged between 10 and 461 cell $\mathrm{ml}^{-1}$, although an exceptionally high abundance (1409 cell $\mathrm{ml}^{-1}$ ) was observed in 1 Antarctic lake (SL Encantado). The abundance of Pseudopedinella spp. did not differ between shallow and deep lakes, though it was significantly higher than in tem-

Fig. 3. Cellular volume of Pseudopedinella spp. in a subset of the studied lakes, ordered according to increasing latitude from left to right. Numbers above the boxplots correspond to the number of cells measured for each lake. Boxes indicate 25th and 75th percentiles; lines indicate median; whiskers indicate 10th and 90th percentiles; circles indicate outliers. P: pond; SL: shallow lake; DL: deep lake 

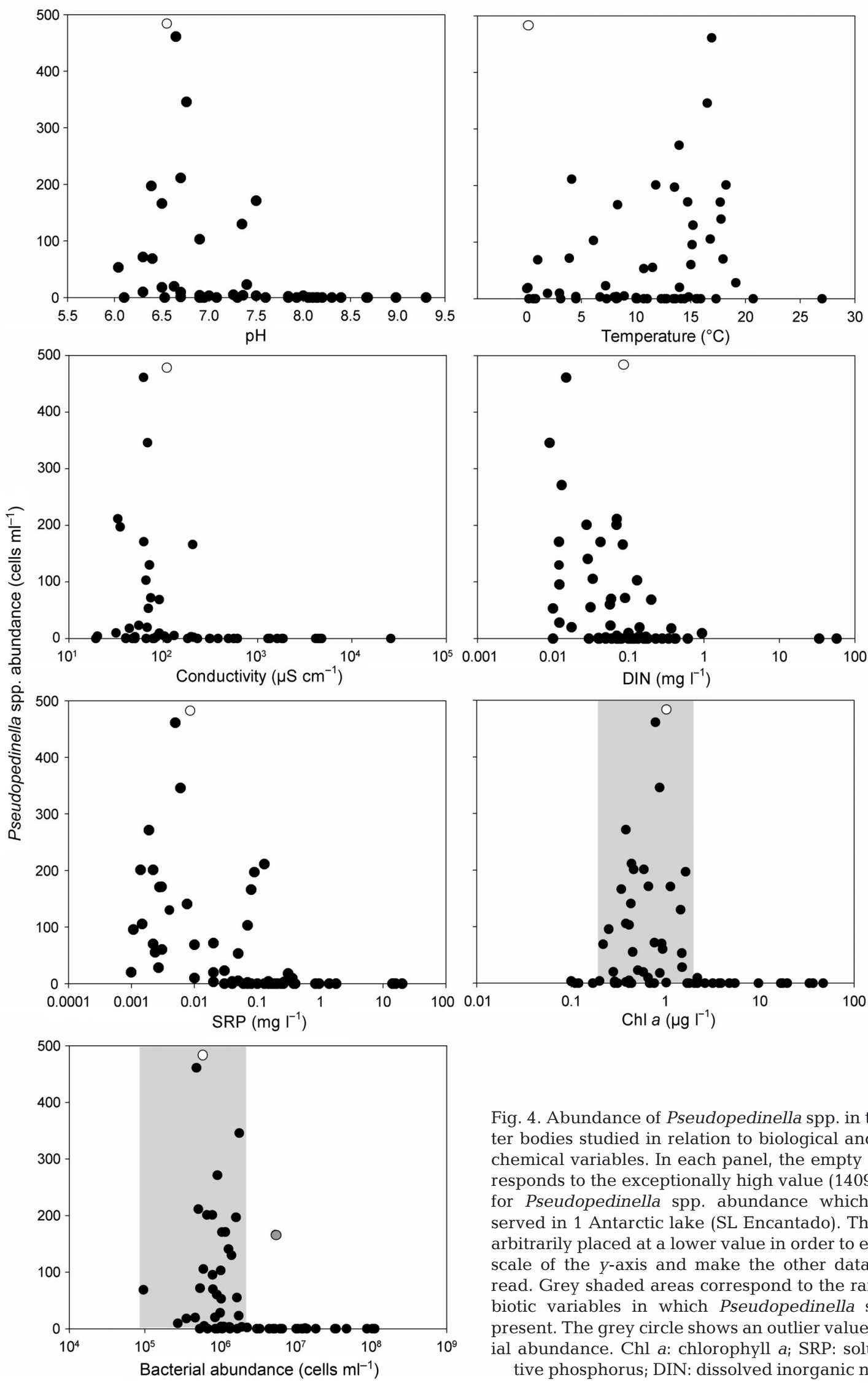

Fig. 4. Abundance of Pseudopedinella spp. in the 54 water bodies studied in relation to biological and physicochemical variables. In each panel, the empty circle corresponds to the exceptionally high value (1409 cell ml-1) for Pseudopedinella spp. abundance which was observed in 1 Antarctic lake (SL Encantado). This circle is arbitrarily placed at a lower value in order to expand the scale of the $y$-axis and make the other data easier to read. Grey shaded areas correspond to the range of the biotic variables in which Pseudopedinella spp. were present. The grey circle shows an outlier value of bacterial abundance. Chl a: chlorophyll $a_{\text {; }}$ SRP: soluble reactive phosphorus; DIN: dissolved inorganic nitrogen 


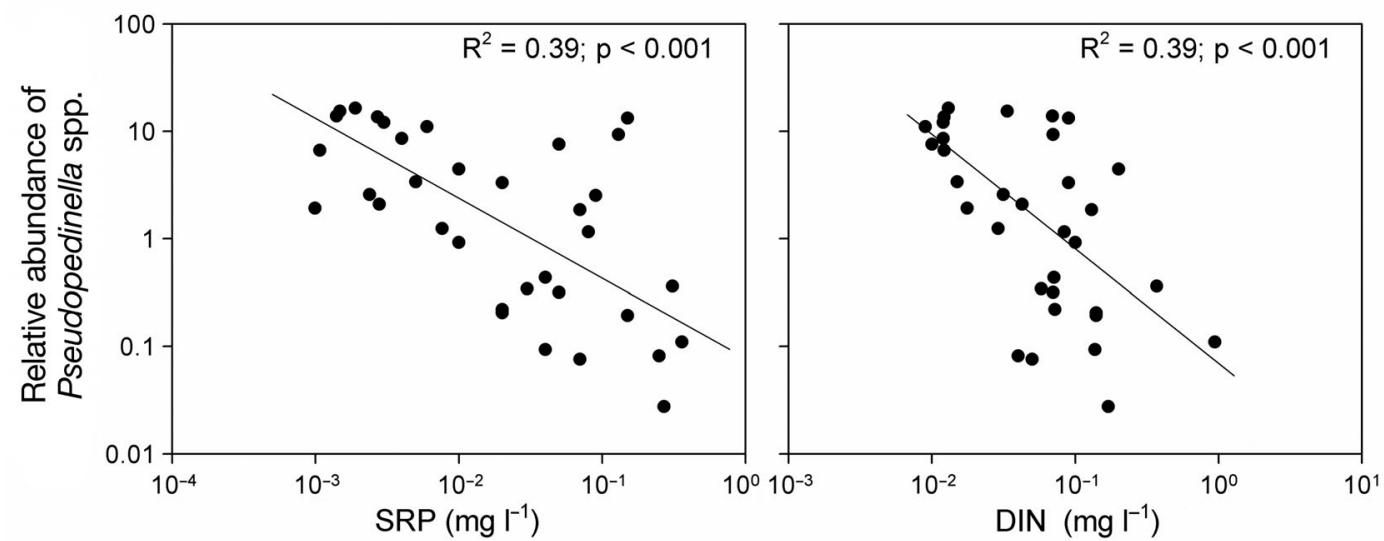

Fig. 5. Relative abundance of Pseudopedinella spp. among total phagotrophic nanoflagellates (mixotrophic and heterotrophic flagellates) in relation to soluble reactive phosphorus (SRP) and dissolved inorganic nitrogen (DIN) availability in the studied lakes

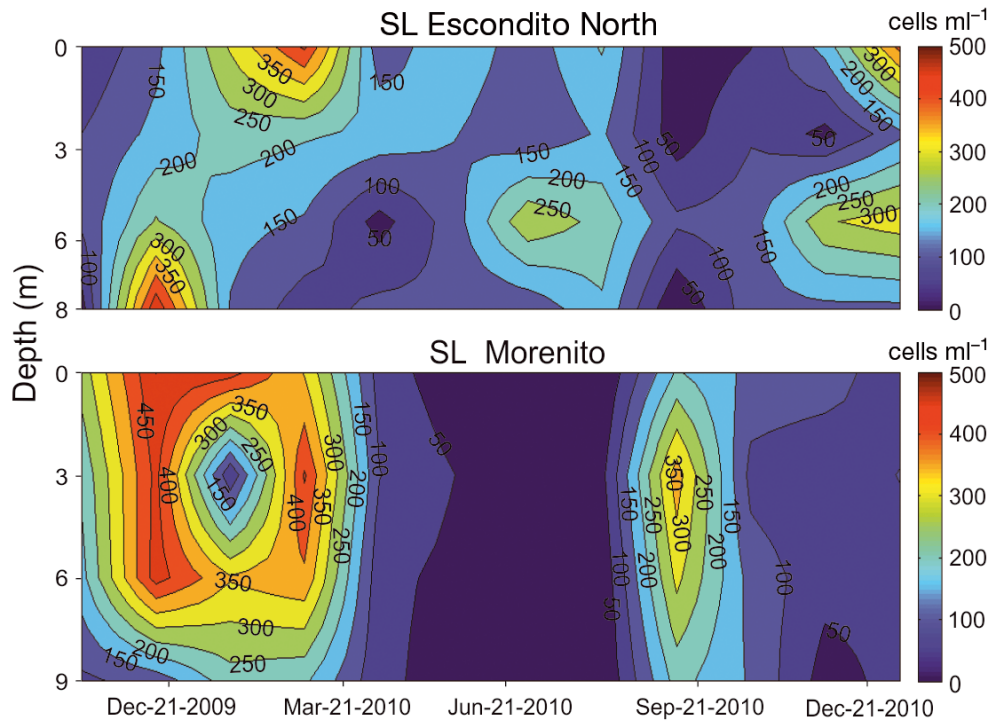

Fig. 6. Vertical and temporal distribution of Pseudopedinella spp. abundance in the shallow lakes (SL) Escondido North (No. 7 in Fig. 1) and Morenito (No. 6), North Patagonia

porary ponds (K-W test: $H=15.711, \mathrm{p}<0.001$, Dunn's posterior test: $\mathrm{p}<0.05)$. Abundance was negatively correlated with $\mathrm{pH}(\mathrm{N}=54, \rho=-0.438$, $\mathrm{p}=0.028)$. The highest abundances were observed at slightly acid water ( $\mathrm{pH}$ values $\sim 6.5)$, while this alga was absent at $\mathrm{pH}$ values $>7.5$ (Fig. 4). Pseudopedinella spp. were found over a wide range of temperature from 0 to $20^{\circ} \mathrm{C}$, and at relatively low conductivity (usually $<90 \mu \mathrm{S} \mathrm{cm}^{-1}$, and never $>210 \mu \mathrm{S}$ $\mathrm{Cm}^{-1}$; Fig. 4). Regression analyses showed that Pseudopedinella spp. abundance was negatively related to DIN concentration $\left(R^{2}=0.12, p=0.039\right)$ and SRP concentration $\left(\mathrm{R}^{2}=0.22, \mathrm{p}=0.004\right)$. Pseudopedinella spp. were absent in lakes with concentrations of $\mathrm{chl} a>2.2 \mu \mathrm{g} \mathrm{l}^{-1}$ and bacterial abundances $>1.7 \times 10^{6}$ cell ml $^{-1}$, except for 1 lake where bacterial abundance reached $5.4 \times 10^{6}$ cells ml ${ }^{-1}$ (Fig. 4). The abundance of Pseudopedinella spp. was negatively correlated with bacterial abundance $(\mathrm{N}=54$, $\rho=-0.29, p=0.019)$. Overall, these results showed that this genus was exclusively found in oligotrophic environments.

In those lakes in which Pseudopedinella spp. was present, it represented between 1 and $23 \%$ (avg. $6.7 \%$ ) of the nanophytoplankton ( 2 to $20 \mu \mathrm{m}$ in size), taking into account all autotrophic and mixotrophic species. Considering the total phagotrophic nanoflagellates $\left(\mathrm{MF}+\mathrm{HF}_{i}\right.$ Table S3 in the Supplement at www.int-res.com/articles/ suppl/a076p219_supp.pdf), Pseudopedinella spp. represented on average $4.7 \%$ of total abundance, ranging from 1.4 to $16.4 \%$. Their relative abundance tended to decrease when dissolved nutrients (SRP and DIN) increased $\left(\mathrm{N}=34 ;\right.$ SRP: $\mathrm{R}^{2}=0.39, \mathrm{p}<0.001 ; \mathrm{DIN}: \mathrm{R}^{2}=0.39$, $\mathrm{p}<0.001$ ) (Fig. 5).

\section{Vertical and temporal distribution of abundance}

Pseudopedinella spp. were present during all the studied year in SL Escondido North and SL Morenito. The latter has lower DOC concentration and higher transparency than SL Escondido North. No clear vertical variation in Pseudopedinella spp. abundance was found in either of the lakes, as a consequence of the permanent mixing of the water column of these polymictic lakes (1-way ANOVA, SL Escondido North: $F=0.831, \mathrm{p}=0.484$; SL Morenito: $F=0.381$, 
$\mathrm{p}=0.767$ ) (Fig. 6). The temporal variation of cell abundance showed 2 peaks recorded in summer and spring in both lakes (Fig. 6). Temporal variation in Pseudopedinella spp. abundance was positively related with temperature $(\mathrm{N}=24$, $\rho=0.446 ; p=0.029$ ), with the maximum abundance at temperature values between 16 and $20^{\circ} \mathrm{C}$, and was negatively affected by DIN concentrations $(\mathrm{N}=24, \rho=-0.447$; $\mathrm{p}=0.028$ ). In this regard, minimum values of Pseudopedinella spp. abundance were observed at the maximum values of DIN.

\section{Bacterivory rates}

Fourteen grazing experiments were performed in 6 oligotrophic water bodies along the latitudinal transect. Pseudopedinella spp. ingested FLB at a significant rate in all of them (Fig. 2a,c). The CSGR was 6.74 bacteria cell ${ }^{-1} \mathrm{~h}^{-1}$ (Table 1), and the lowest values were recorded in Antarctic lakes, probably because of the low temperature in these environments. CSGR and temperature fitted to a hyperbolic function in which the CSGR steeply increased with water temperature, up to about $6^{\circ} \mathrm{C}$ (Fig. 7), while above this value it fluctuated around the average CSGR (2.83 bacteria cell ${ }^{-1} \mathrm{~h}^{-1}$; Table 1). Interestingly, CSGR decreased significantly together with the increase in DIN concentration $\left(\mathrm{N}=14, \mathrm{R}^{2}=0.53, \mathrm{p}=0.003\right.$; Fig. 7), and increased with bacterial abundance $\left(\mathrm{N}=14, \mathrm{R}^{2}=0.61, \mathrm{p}=\right.$ 0.001; Fig. 7). Stepwise multiple regressions found bacterial abundance to be the only significant variable, and it explained the $61 \%$ (p < 0.001) of the variability in CSGR.

The $\mathrm{CR}$ was variable among lakes and averaged $3.28 \mathrm{nl}$ cell $^{-1} \mathrm{~h}^{-1}$ (Table 1). This parameter was negatively related to bacterial abun-

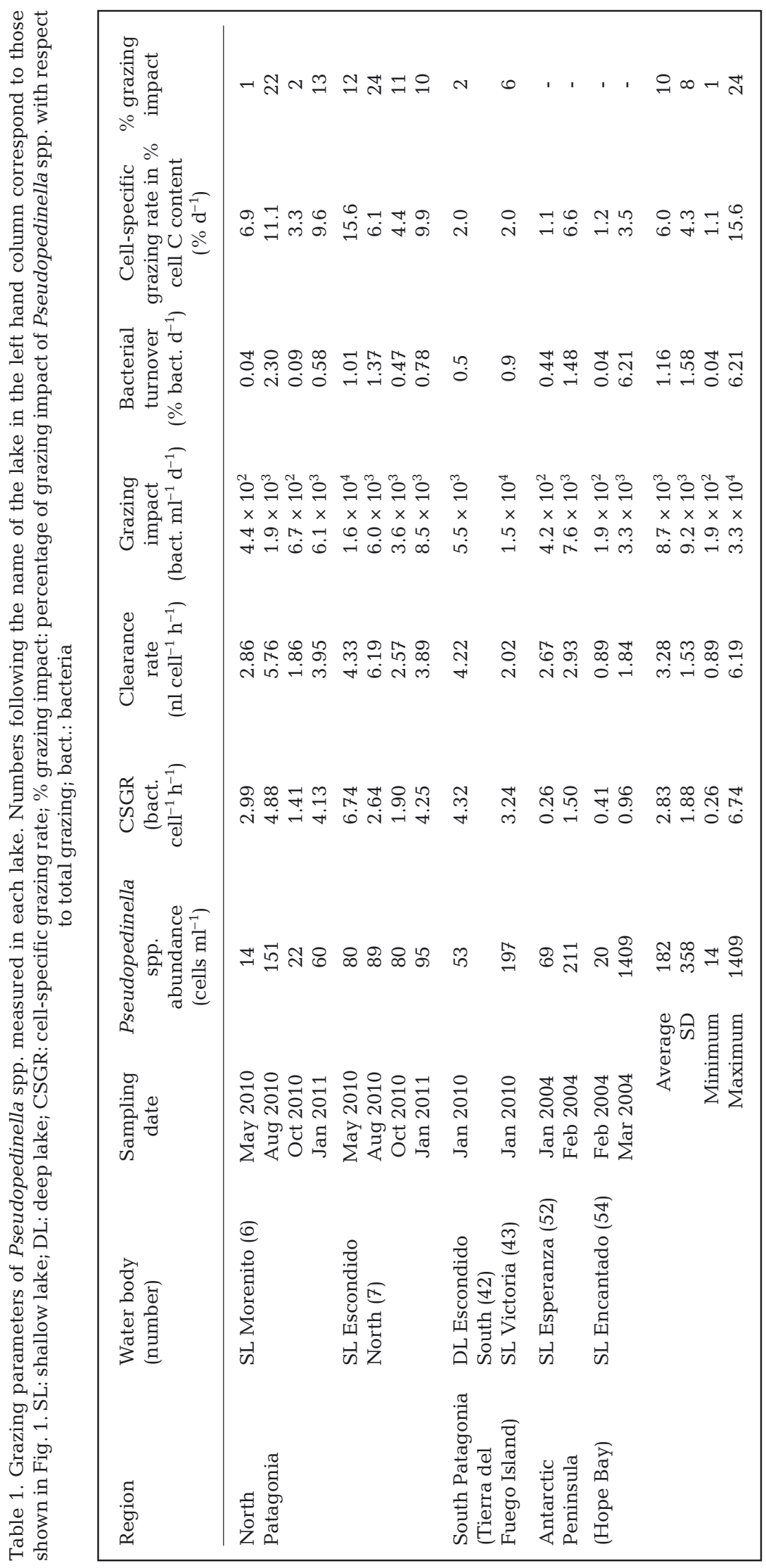



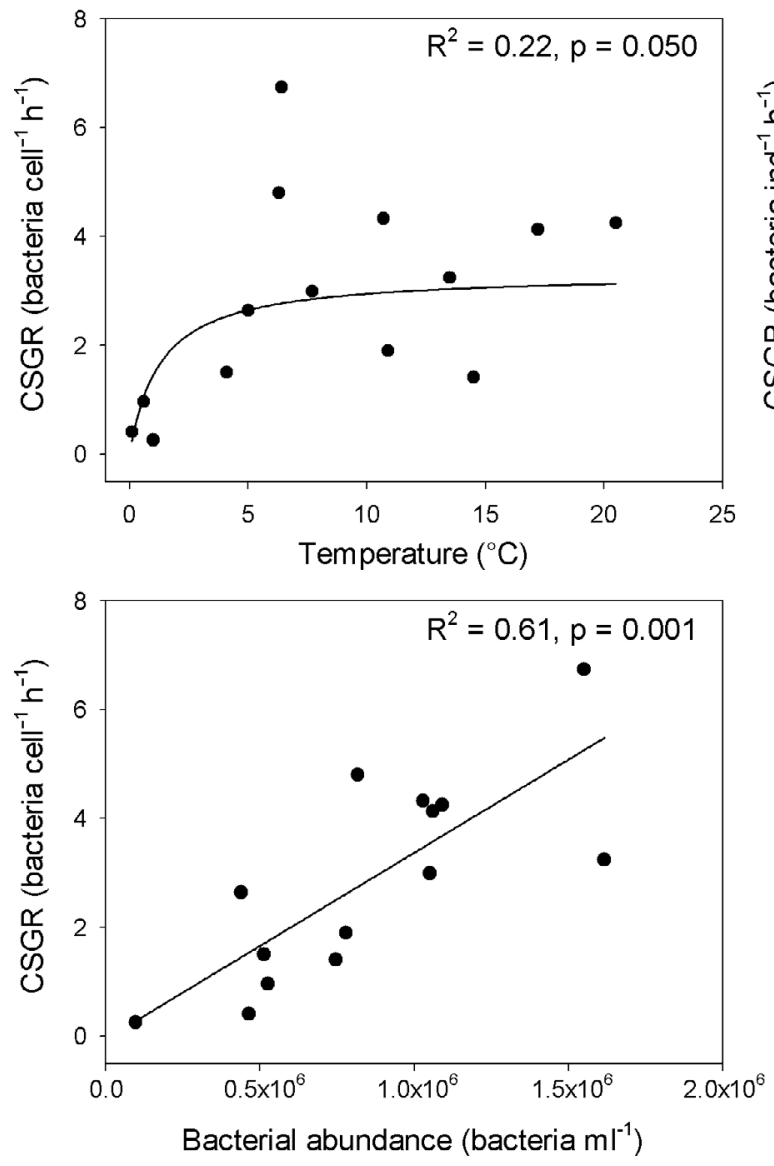

dance $(\mathrm{N}=14, \rho=-0.475, \mathrm{p}=0.047)$. The CSGR expressed as percentage of the cellular carbon per day varied between 1.1 and $15.6 \% \mathrm{~d}^{-1}$ (Table 1).

This single genus removed up to $6.2 \%$ of the bacterial standing stock per day during periods of relatively high abundance (Table 1). Pseudopedinella spp. grazing caused an average impact on the bacterial community of $8.7 \times 10^{3}$ bacteria $\mathrm{ml}^{-1} \mathrm{~d}^{-1}$. Total GI by phagotrophic flagellates (MF and HF) was estimated in 10 out of 14 experiments. Even though Pseudopedinella spp. never exceeded $20 \%$ of the abundance of total bacterivores (avg. 4.7\%), in our experiments up to $24 \%$ of the total GI was due to this alga (Table 1).

\section{DISCUSSION}

The morphological analysis of Pseudopedinella along a broad spectrum of physico-chemical conditions showed a marked variability in cell size (i.e. cell diameter ranged between 3.4 and $7 \mu \mathrm{m}$ ). Such variability could be explained by the presence of more than 1 species in our samples. Supporting this hypo-

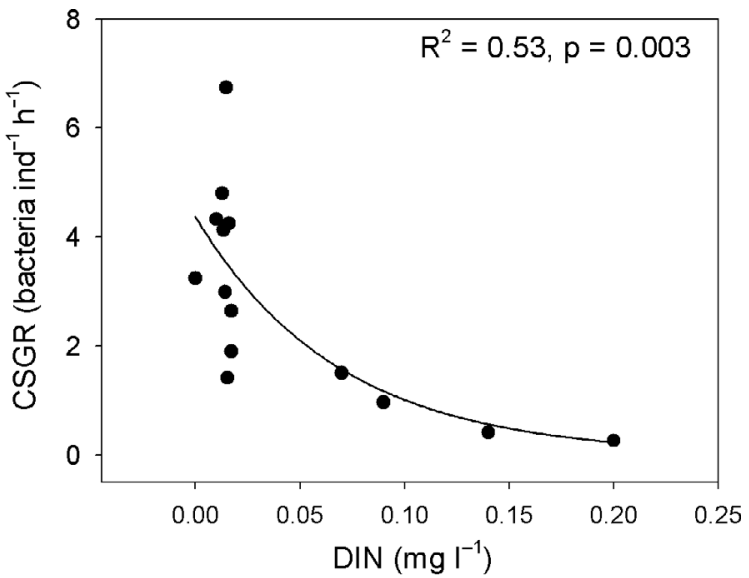

Fig. 7. Cell-specific grazing rates (CSGR) of Pseudopedinella spp. in relation to biological and physico-chemical variables. DIN: dissolved inorganic nitrogen

thesis, individuals with 3 and 6 chloroplasts were observed. Seven species of Pseudopedinella are mentioned in the literature (Sekiguchi et al. 2003; Table S1 in the Supplement). However, based on Guiry \& Guiry (2015), there are 3 confirmed species: $P$. pyriformis ('pyriforme', as the Holotype of the genus), $P$. elastica and $P$. thomsenii, while the confirmation of a fourth species of this genus ( $P$. erkensis) is considered to require further investigation. The individuals with 3 chloroplasts correspond to $P$. thomsenii (Sekiguchi et al. 2003), which is the only species of this genus which possesses 3 chloroplasts (Thomsen 1988). The individuals with 6 chloroplasts could not be determined to a finer taxonomic detail, which requires observation of ultrastructural features. $P$. elastica and $P$. erkensis were previously mentioned in freshwater environments (Table S1 in the Supplement), so the specimens with 6 chloroplasts present in our samples could correspond to either of these species. Besides, phenotypic plasticity can also explain the observed variation in cell size, as can factors such as light (O'Farrell et al. 2007), nutrient availability (Li et al. 2000), temperature (Morabito et al. 2007) and grazing (De Hoyos et al. 1998), which 
have been proven to influence the morphology of other algal groups.

The presence of Pseudopedinella spp. seems not to be constrained by water temperature, as we found specimens in the coldest Antarctic shallow lakes (close to $0^{\circ} \mathrm{C}$ ) and the North Patagonian lakes where temperature reached up to $20^{\circ} \mathrm{C}$ in summer. In accordance with our results, $P$. pyriformis has been also found in a wide range of temperatures (between 2 and $19^{\circ} \mathrm{C}$ ) in marine environments (Ostroff et al. 1980). Nevertheless, in our study, higher abundances were recorded in spring and summer in the annual survey (avg. $14.3^{\circ} \mathrm{C}$, range 7 to $20^{\circ} \mathrm{C}$ ), and between 15 and $20^{\circ} \mathrm{C}$ when all studied lakes were compared. For marine P. pyriformis, maximum in situ growth rate was observed at $15^{\circ} \mathrm{C}$ (Ostroff et al. 1980). Phagotrophic behaviour agreed with this pattern: CSGR increased with temperature between 0 and $6^{\circ} \mathrm{C}$, and had little variation at higher temperatures.

In our samples, Pseudopedinella spp. were restricted to oligotrophic environments, with low chl a and nutrient concentrations, and low bacterial abundances. Moreover, the relative abundance of Pseudopedinella spp. was negatively related to nutrient concentration, suggesting also a preference for nutrient-poor waters. Even though this genus was sporadically found growing well in experiments with nutrient enrichments (Lagus et al. 2004), most records of Pseudopedinella in marine and freshwater environments correspond to nutrient-poor waters (Rosén 1981, Hearing 1984, De Hoyos et al. 1998, Olrik 1998, Hobbie et al. 2000, Unrein et al. 2005, 2014, Gerea et al. 2013). In contrast to our results, some long-term investigations carried out in the Baltic Sea found a positive relationship between the abundance of Pseudopedinella spp. and nitrogen concentration (Carstensen \& Heiskanen 2007, Suikkanen et al. 2007, 2013). However, values of DIN measured in the Baltic Sea (usually $<0.1 \mathrm{mg} \mathrm{l}^{-1}$ ) fall within the range of values determined in our study, but are far less than the maximum DIN levels where Pseudopedinella spp. were present in our study (Fig. 4). Thus, although in some cases individual samples could be misleading, we found a great consistency between Pseudopedinella spp. distribution and the trophic condition of the sampled aquatic systems. We consider that the eventual sampling bias (i.e. only 1 sample per lake in most environments) is minimized because the intra-lake variability would be lower than the between-lake variability in this kind of study. If we had employed a different sampling strategy in our widespread survey (i.e. several samples in each system) we probably could have found differences in Pseudopedinella spp. abundances, but it can be expected that nutrient concentrations would have remained in the same range, meaning that the probability that the trophic condition of the lakes changes with depth or time is very low.

In accordance with the preference of Pseudopedinella spp. for nutrient-poor environments, we observed that the CSGR was negatively related with the availability of dissolved inorganic nutrients. Many experiments with cultured and field mixotrophic flagellates demonstrate that grazing rates decrease after the addition of inorganic nutrients (Nygaard \& Tobiesen 1993, Rothhaupt 1996a, Zubkov \& Tarran 2008, Smalley et al. 2012); this is because nutrient assimilation in particulate form is energetically more costly than absorbing nutrients in dissolved inorganic form (Raven 1997). These results predict that an inverse relationship should be expected between dissolved inorganic nutrient concentrations and the in situ phagotrophic activity of mixotrophs, as was observed for Pseudopedinella spp. in our study. This also suggests that the growth of this alga depends on the mixotrophic nutrition in environments with low nitrogen and phosphorus concentrations. This assertion, although requiring confirmation by means of experimental assessments, supports the idea that phagotrophy is a way to supplement nutrients when these are limiting (Nygaard \& Tobiesen 1993, Rothhaupt 1996a, Flöder et al. 2006, Carvalho \& Granéli 2010). Vähätalo et al. (2011) proposed that Pseudopedinella is capable of growing autotrophically but grazes on bacteria under nutrient limiting conditions. The pattern observed here for Pseudopedinella spp. has also been recorded in some cryptophytes (Urabe et al. 2000, Unrein et al. 2014), haptophytes (Nygaard \& Tobiesen 1993, Carvalho \& Granéli 2010), prasinophytes (McKie-Krisberg et al. 2015), chrysophytes (Nygaard \& Tobiesen 1993, Urabe et al. 2000) and dinoflagellates (Nygaard \& Tobiesen 1993, Stoecker et al. 1997). This would partially explain the success of mixotrophs in oligotrophic systems that has been observed in natural environments as well as in experimental conditions (Olrik 1998, Hartmann et al. 2012, Unrein et al. 2014).

The values of CSGR (0.3 to 6.7 bacteria cell ${ }^{-1} \mathrm{~h}^{-1}$ ) obtained in our experiments are in line with the rates estimated by Havskum \& Riemann (1996) in a marine system ( 1 to 2 bacteria cell ${ }^{-1} \mathrm{~h}^{-1}$ ) using the same methodology that we used. Previous research using radiolabeled (RLB) instead of fluorescently labeled bacteria (FLB) reported a CSGR of 18 bacteria cell $^{-1}$ $\mathrm{h}^{-1}$ for one strain of Pseudopedinella sp. (Nygaard \& Tobiesen 1993). The available values of CR (Nygaard 
\& Tobiesen 1993, Havskum \& Riemann 1996, the present study) range between 0.9 and $6.2 \mathrm{nl} \mathrm{cell}^{-1} \mathrm{~h}^{-1}$. These rates of bacterivory are comparable to those observed for highly bacterivorous chrysophytes, like Dinobryon (see review by Unrein et al. 2010) and Ochromonas (Sanders et al. 1990, Epstein \& Shiaris 1992, Callieri et al. 2006), and for HF of similar cell size (Laybourn-Parry \& Marshall 2003, Jezbera et al. 2005, Pirlot et al. 2007, Unrein et al. 2007). Another indication of the relative importance of heterotrophic nutrition in Pseudopedinella spp. is the relatively high cell-specific ingestion rate, measured as percentage of cell carbon per day (between 1.1 and $\left.15.6 \% \mathrm{~d}^{-1}\right)$. These values are similar to those reported for HF (Pernthaler et al. 1996, Unrein et al. 2007), chrysophytes (Izaguirre et al. 2012) and haptophytes (Unrein et al. 2014), and notably higher than those observed for the less bacterivorous cryptophytes (Unrein et al. 2014).

Interestingly, the increase of CSGR with the increment of bacterial abundance observed in this study for Pseudopedinella spp. corresponds to a functional response typical of heterotrophic protists (Fenchel 1982, Kiørboe et al. 2004). Similar patterns were observed for some highly heterotrophic chrysophytes like Ochromonas sp. and Poterioochromonas malhamensis (Rothhaupt 1996b, Rottberger et al. 2013). Overall, these results suggest that Pseudopedinella is a very active bacterivore and, according to the gradient spectrum proposed by Jones (1994) and the more recent review by Flynn et al. (2013), should be considered a highly heterotrophic photosynthetic protist.

Previous investigations mentioned that Pseudopedinella species often occur in low abundance (Havskum \& Riemann 1996, Gerea et al. 2013). Coincidently, in all the studied water bodies in which Pseudopedinella spp. were present, their abundance rarely exceeded 400 cells $\mathrm{ml}^{-1}$, and never dominated among phytoplankton (average $6.7 \%$ ). However, this single genus accounted for up to $24 \%$ of total grazing impact, a result that highlights the significant impact that Pseudopedinella might have in oligotrophic waters. In this sense, it is important to underline that in a recent grazing experiment we also detected a high consumption of picocyanobacteria (Synechoccocus sp.) by this genus in 2 lakes of North Patagonia (M. Gerea et al. unpubl. data). Grazing of picocyanobacteria by Dictyochophyceae was also observed in marine environments (Frías-López et al. 2009). These results support the idea that this group is a strong picoplanktonic grazer.

In summary, Pseudopedinella organisms were found mainly in oligotrophic environments and ap- peared to use phagotrophy to additionally acquire essential nutrients when these substances are limiting. In spite of their usually low abundance, their highly bacterivorous behavior resulted in a potentially high grazing impact on the bacterioplankton community, positioning this algae as a relevant component likely channelizing a relevant share of the C fluxes in some nutrient-poor environments.

Acknowledgements. We thank Rodrigo Sinistro, M. Laura Sánchez, Cristina Marinone, Guillermo Tell, Adrian Rua, M. Romina Schiaffino and Enrique Moreno Díaz for their collaboration during different field campaigns. We are also grateful to the members of Antarctic Esperanza Station for their logistic support and to Amalia Denegri for her helpful support with the editing of the maps. This study was financed by the Consejo Superior de Investigaciones Científicas-Consejo Nacional de Investigaciones Científicas y Técnicas (CSIC-CONICET) (Spain-Argentina) Project PROBA (2007 AR0018, CSIC), the Spanish Project MIXANTAR (REN 2002-11396-E/ ANT) and the Argentinean FONCYT projects PICT 01-06035, PICT 32732, CONICET PIP 418 and UBACYT Y 018. M.G. and J.F.S. were supported by CONICET fellowships. I.I., C.Q. and F.U. are CONICET researchers. J.M.G. is a CSIC researcher.

\section{LITERATURE CITED}

Biecheler B (1936) Observation de la capture et de la digestion des protes chez un peridinén vert. C R Séances Soc Biol 12:1173-1175

Bird DF, Kalff J (1986) Bacterial grazing by planktonic lake algae. Science 231:493-495

Callieri C, Corno G, Bertoni R (2006) Bacterial grazing by mixotrophic flagellates and Daphnia longispina: a comparison in a fishless alpine lake. Aquat Microb Ecol 42: 127-137

Callieri C, Modenutti B, Queimaliños C, Bertoni R, Balseiro E (2007) Production and biomass of picophytoplankton and larger autotrophs in Andean ultraoligotrophic lakes: differences in light harvesting efficiency in deep layers. Aquat Ecol 41:511-523

Carstensen J, Heiskanen AS (2007) Phytoplankton responses to nutrient status: application of a screening method to the northern Baltic Sea. Mar Ecol Prog Ser 336:29-42

Carvalho WF, Granéli E (2010) Contribution of phagotrophy versus autotrophy to Prymnesium parvum growth under nitrogen and phosphorus sufficiency and deficiency. Harmful Algae 9:105-115

$>$ De Hoyos C, Aldasoro JJ, Toro M, Comín FA (1998) Specific composition and ecology of chrysophyte flagellates in Lake Sanabria (NW Spain). Hydrobiologia 369/370: 287-295

Epstein SS, Shiaris MP (1992) Size-selective grazing of coastal bacterioplankton by natural assemblages of pigmented flagellates, colorless flagellates, and ciliates. Microb Ecol 23:211-225

> Fenchel T (1982) Ecology of heterotrophic microflagellates. II. Bioenergetics and growth. Mar Ecol Prog Ser 8: 225-231

Flöder S, Hansen T, Ptacnik R (2006) Energy-dependent bacterivory in Ochromonas minima - a strategy promot- 
ing the use of substitutable resources and survival at insufficient light supply. Protist 157:291-302

> Flynn KJ, Stoecker DK, Mitra A, Raven JA and others (2013) Misuse of the phytoplankton-zooplankton dichotomy: the need to assign organisms as mixotrophs within plankton functional types. J Plankton Res 35:3-11

Frías-López J, Thompson A, Waldbauer J, Chisholm SW (2009) Use of stable isotope-labelled cells to identify active grazers of picocyanobacteria in ocean surface waters. Environ Microbiol 11:512-525

Gasol JM, Pinhassi J, Alonso-Sáez L, Ducklow H and others (2008) Towards a better understanding of microbial carbon flux in the sea. Aquat Microb Ecol 53:21-38

Gerea M (2013) La implicancia de las algas mixotróficas en la trama trófica microbiana de lagos someros oligotróficos de Patagonia norte y de la península Antártica (Argentina). $\mathrm{PhD}$ thesis, Universidad Nacional del Comahue

> Gerea M, Queimalinos C, Schiaffino MR, Izaguirre I, Forn I, Massana R, Unrein F (2013) In situ prey selection of mixotrophic and heterotrophic flagellates in Antarctic oligotrophic lakes: an analysis of the digestive vacuole content. J Plankton Res 35:201-212

Guiry MD, Guiry GM (2015) AlgaeBase. National University of Ireland, Galway. www.algaebase.org

> Hartmann M, Grob C, Tarran GA, Martin AP, Burkill PH, Scanlan DJ, Zubkov MV (2012) Mixotrophic basis of Atlantic oligotrophic ecosystems. Proc Natl Acad Sci USA 109:5756-5760

Havskum H, Riemann B (1996) Ecological importance of bacterivorous, pigmented flagellates (mixotrophs) in the Bay of Aarhus, Denmark. Mar Ecol Prog Ser 137:251-263

Hearing F (1984) Pseudopedinella, un género de las crisofíceas de agua dulce. Ann Biol 2:101-106

Hibberd DJ (1986) Ultrastructure of the Chrysophyceae: phylogenetic implications and taxonomy. In: Kristiansen J, Andersen RA (eds) Chrysophytes: aspect and problems, Cambridge University Press, Cambridge, p 23-36

Hobbie JE, Bahr M, Bettez N, Rublee PA (2000) Microbial food webs in oligotrophic arctic lakes. In: Bell C, Brylinksy M, Johnson-Green P (eds) Microbial biosystems: new frontiers. Proc 8th Int Symp Microbial Ecology, Halifax, Aug 9-14, 1998. Atlantic Canada Society for Microbial Ecology, Halifax, p 293-298

Iriondo M (1989) Quaternary lakes of Argentina. Palaeogeogr Palaeoclimatol Palaeoecol 70:81-88

> Izaguirre I, Vinocur A, Mataloni G, Pose M (1998) Phytoplankton communities in relation to trophic status in lakes from Hope Bay (Antarctic Peninsula). Hydrobiologia 369/370:73-87

> Izaguirre I, Allende LUZ, Marinone MC (2003) Comparative study of the planktonic communities of three lakes of contrasting trophic status at Hope Bay (Antarctic Peninsula). J Plankton Res 25:1079-1097

Izaguirre I, Sinistro R, Schiaffino MR, Sánchez ML, Unrein F, Massana R (2012) Grazing rates of protists in wetlands under contrasting light conditions due to floating plants. Aquat Microb Ecol 65:221-232

Jeong HJ, Seong KA, Kang NS, Yoo YD and others (2010) Feeding by raphidophytes on the cyanobacterium Synechococcus sp. Aquat Microb Ecol 58:181-195

> Jezbera J, Hornák K, Simek K (2005) Food selection by bacterivorous protists: insight from the analysis of the food vacuole content by means of fluorescence in situ hybridization. FEMS Microbiol Ecol 52:351-363

Jones RI (1994) Mixotrophy in planktonic protist as a spec- trum of nutritional strategies. Mar Microb Food Webs 8: $87-96$

Jones RI (2000) Mixotrophy in planktonic protists: an overview. Freshw Biol 45:219-226

> Kiørboe T, Grossart H, Ploug H, Tang K, Auer B (2004) Particle-associated flagellates: swimming patterns, colonization rates, and grazing on attached bacteria. Aquat Microb Ecol 35:141-152

Kristiansen J (1990) Phylum Chrysophyta. In: Margulis L, Corliss JO, Melkonian M, Chapman DJ (eds) Handbook of protoctista, Jones \& Bartlett, Boston, MA, p 438-453

> Kristiansen J, Sandgren CD (1986) The ultrastructural bases of chrysophyte systematics and phylogeny. Crit Rev Plant Sci 4:149-211

> Lagus A, Soumela J, Weithoff G, Heikkelä K, Helminen H, Sipura J (2004) Species-specific differences in phytoplankton responses to $\mathrm{N}$ and $\mathrm{P}$ enrichments and the $\mathrm{N}: \mathrm{P}$ ratio in the Archipelago Sea, northern Baltic Sea. J Plankton Res 26:779-798

> Laybourn-Parry J, Marshall WA (2003) Photosynthesis, mixotrophy and microbial plankton dynamics in two high Arctic lakes during summer. Polar Biol 26:517-524

> Lee S, Fuhrman JA (1987) Relationships between biovolume and biomass of naturally derived marine bacterioplankton. Appl Environ Microbiol 53:1298-1303

Li A, Stoecker DK, Coats DW (2000) Mixotrophy in Gyrodinium galatheanum (Dinophyceae): grazing responses to light intensity and inorganic nutrients. J Phycol 36:33-45

Maruyama S, Kim E (2013) A modern descendant of early green algal phagotrophs. Curr Biol 23:1081-1084

McKie-Krisberg ZM, Gast RJ, Sanders RW (2015) Physiological responses of three species of Antarctic mixotrophic phytoflagellates to changes in light and dissolved nutrients. Microb Ecol 70:21-29

Menden-Deuer S, Lessard EJ (2000) Carbon to volume relationships for dinoflagellates, diatoms, and other protist plankton. Limnol Oceanogr 45:569-579

> Morabito G, Oggioni A, Caravati E, Panzani P (2007) Seasonal morphological plasticity of phytoplankton in Lago Maggiore (N. Italy). Hydrobiologia 578:47-57

- Nygaard K, Tobiesen A (1993) Bacterivory in algae: a survival strategy during nutrient limitation. Limnol Oceanogr 38:273-279

O'Farrell I, Tezanos Pinto P, Izaguirre I (2007) Phytoplankton morphological response to the underwater light conditions in a vegetated wetland. Hydrobiologia 578:65-77

Olrik K (1998) Ecology of mixotrophic flagellates with special reference to Chrysophyceae in Danish lakes. Hydrobiologia 369/370:329-338

Ostroff C, Karlander E, Van Valkenburg S (1980) Growth rates of Pseudopedinella pyriforme (Chrysophyceae) in response to 75 combinations of light, temperature and salinity. J Phycol 16:421-423

Paruelo JM, Beltrán A, Jobbágy E, Sala OE, Rodolfo A (1998) The climate of Patagonia: general patterns and controls on biotic processes. Ecología Austral 8:85-101

> Pernthaler J, Sattler B, Šimek K, Schwarzenbacher A, Psenner R (1996) Top-down effects on the size-biomass distribution of a freshwater bacterioplankton community. Aquat Microb Ecol 10:255-263

> Pirlot S, Unrein F, Descy JP, Servais P (2007) Fate of heterotrophic bacteria in Lake Tanganyika (East Africa). FEMS Microbiol Ecol 62:354-364

> Porter KG (1988) Phagotrophic phytoflagellates in microbial food webs. Hydrobiologia 159:89-97 
Porter KG, Feig Y (1980) The use of DAPI for identifying aquatic microflora. Limnol Oceanogr 25:943-948

Queimaliños C (2002) The role of phytoplanktonic size fractions in the microbial food webs in two north Patagonian lakes (Argentina). Arch Hydrobiol 28: 1236-1240

Queimaliños C, Diaz M (2014) Phytoplankton of Andean Patagonian lakes. In: Tell G, Izaguirre I, O'Farrell I (eds) Freshwater phytoplankton of Argentina. Schweizerbart, Stuttgart, p 235-256

Quirós R, Drago E (1999) The environmental state of Argentinean lakes: an overview. Lakes Reserv Res Manag 4: 55-64

Raven J (1997) Phagotrophy in phototrophs. Limnol Oceanogr 42:198-205

Rice JA (1988) Mathematical statistics and data analysis. Wadsworth, Belmont, CA

Rosén G (1981) Phytoplankton indicators and their relations to certain chemical and physical factors. Limnologica 13: 2263-2290

Rothhaupt KO (1996a) Utilization of substitutable carbon and phosphorus sources by the mixotrophic chrysophyte Ochromonas sp. Ecology 77:706-715

Rothhaupt KO (1996b) Laboratory experiments with a mixotrophic chrysophyte and obligately phagotrophic and phototrophic competitors. Ecology 77:716-724

Rottberger J, Gruber A, Boenigk J, Kroth PG (2013) Influence of nutrients and light on autotrophic, mixotrophic and heterotrophic freshwater chrysophytes. Aquat Microb Ecol 71:179-191

Saad JF, Schiaffino MR, Vinocur A, O'Farrell I, Tell G, Izaguirre I (2013) Microbial planktonic communities of freshwater environments from Tierra del Fuego: dominant trophic strategies in lakes with contrasting features. J Plankton Res 35:1220-1233

Sanders RW, Porter KG, Bennett SJ, Debiase AE (1989) Seasonal patterns of bacterivory by flagellates, ciliates, rotifers, and cladocerans in a freshwater planktonic community. Limnol Oceanogr 34:673-687

Sanders RW, Porter KG, Caron DA (1990) Relationship between phototrophy and phagotrophy in the mixotrophic chrysophyte Poterioochromonas malhamensis. Microb Ecol 19:97-109

Schiaffino MR, Unrein F, Gasol JM, Massana R, Balagué V, Izaguirre I (2011) Bacterial community structure in a latitudinal gradient of lakes: the roles of spatial versus environmental factors. Freshw Biol 56:1973-1991

Schmidtke A, Bell EM, Weithoff G (2006) Potential grazing impact of the mixotrophic flagellate Ochromonas sp. (Chrysophyceae) on bacteria in an extremely acidic lake. J Plankton Res 28:991-1001

Sekiguchi H, Kawachi M, Nakayama T, Inouye I (2003) A taxonomic re-evaluation of the Pedinellales (Dictyochophyceae), based on morphological, behavioural and molecular data. Phycologia 42:165-182

Smalley GW, Wayne Coats D, Stoecker DK (2012) Influence of inorganic nutrients, irradiance, and time of day on

Editorial responsibility: Urania Christaki,

Wimereux, France food uptake by the mixotrophic dinoflagellate Neoceratium furca. Aquat Microb Ecol 68:29-41

Stauffer BA, Schaffner R, Wazniak C, Caron D (2008) Immunofluorescence flow cytometry technique for enumeration of the brown-tide alga, Aureococcus anophagefferens. Appl Environ Microbiol 74:6931-6940

Stoecker DK (1998) Conceptual models of mixotrophy in planktonic protists and some ecological and evolutionary implications. Eur J Protistol 34:281-290

$>$ Stoecker DK (1999) Mixotrophy among dinoflagellates. J Eukaryot Microbiol 46:397-401

> Stoecker DK, Li A, Coats DW, Gustafson DE, Nannen MK (1997) Mixotrophy in the dinoflagellate Prorocentrum minimum. Mar Ecol Prog Ser 152:1-12

Suikkanen S, Laamanen M, Huttunen M (2007) Long-term changes in summer phytoplankton communities of the open northern Baltic Sea. Estuar Coast Shelf Sci 71: 580-592

Suikkanen S, Pulina S, Engström-Öst J, Lehtiniemi M, Lehtinen S, Brutemark A (2013) Climate change and eutrophication induced shifts in northern summer plankton communities. PLoS ONE 8:e66475

> Sun J, Liu D (2003) Geometric models for calculating cell biovolume and surface area for phytoplankton. J Plankton Res 25:1331-1346

Thomsen H (1988) Ultrastructural studies of the flagellate and cyst stages of Pseudopedinella tricostata (Pedinellales, Chrysophyceae). Br Phycol J 23:1-16

Tranvik LJ, Porter KG, Sieburth JM (1989) Occurrence of bacterivory in Cryptomonas, a common freshwater phytoplankter. Oecologia 78:473-476

- Unrein F, Izaguirre I, Massana R, Balagué V, Gasol JM (2005) Nanoplankton assemblages in maritime Antarctic lakes: characterisation and molecular fingerprinting comparison. Aquat Microb Ecol 40:269-282

Unrein F, Massana R, Alonso-Sáez L, Gasol JM (2007) Significant year-round effect of small mixotrophic flagellates on bacterioplankton in an oligotrophic coastal system. Limnol Oceanogr 52:456-469

Unrein F, Gasol JM, Massana R (2010) Dinobryon faculiferum (Chrysophyta) in coastal Mediterranean seawater: presence and grazing impact on bacteria. J Plankton Res 32:559-564

Unrein F, Gasol JM, Not F, Forn I, Massana R (2014) Mixotrophic haptophytes are key bacterial grazers in oligotrophic coastal waters. ISME J 8:164-176

- Urabe J, Gurung TB, Yoshida T, Sekino T, Nakanishi M, Maruo M, Nakayama E (2000) Diel changes in phagotrophy by Cryptomonas in Lake Biwa. Limnol Oceanogr 45:1558-1563

> Vähätalo AV, Aarnos H, Hoikkala L, Lignell R (2011) Photochemical transformation of terrestrial dissolved organic matter supports hetero- and autotrophic production in coastal waters. Mar Ecol Prog Ser 423:1-14

- Zubkov MV, Tarran GA (2008) High bacterivory by the smallest phytoplankton in the North Atlantic Ocean. Nature 455:224-226

Submitted: October 10, 2015; Accepted: December 2, 2015 Proofs received from author(s): January 31, 2016 